\title{
Analisis Image Comments to Followers Ratio Instagram Pada 5 Pemain Dengan Gaji Tertinggi di Chelsea
}

\author{
I MADE HENDRY RIKAYANA
}

15101260

hendryrikayana@gmail.com

\begin{abstract}
Instagram is a very global social media application, almost all Android/IOS users have an Instagram application. It is very easy to use this application and quite addictive for users. In Indonesia, there are approximately 91.77 million users, most of the users are aged 18-24 years, which is around $36.4 \%$ of the total. The rise of Instagram users in Indonesia which of course can provide opportunities for brands to sell or promote their wares and can earn for individuals because of high followers so that people are endorsed by a brand and of course can make money depending on contracts and agreements between brands and agreements. supporters. The five highest-paid players at Chelsea who use Instagram as a marketing platform are: Kepa Arizabalaga, Ben Chilwell, Timo Werner, N'Golo Kante and Romelu Lukaku. The purpose of this study was to calculate the credibility of the Image Comments to Followers Ratio of the highest-paid players at Chelsea. The method used for this research is exploratory quantitative method. The results of this study indicate that the Kepa Arizabalaga player gets the first rank and has good account performance credibility.
\end{abstract}

\begin{abstract}
ABSTRAK
Instagram merupakan aplikasi social media yang sangat mendunia, hampir semua pengguna android/IOS memiliki aplikasi Instagram. Sangatlah mudah menggunakan aplikasi ini dan cukup membuat candu bagi penggunanya. Di Indonesia terdapat kurang lebih 91,77 juta pengguna saat ini yang penggunanya sebagian besar berusia 18 - 24 tahun yaitu sekitar 36,4\% dari keseluruhannya. Maraknya pengguna Instagram di Indonesia yang aktif tentu dapat memberikan peluang bagi brand untuk menjual atau mempromosikan barang dagangannya serta bisa juga menghasilkan untuk perorangan karena memiliki follower yang tinggi sehingga orang tersebut diendor oleh sebuah brand dan tentu saja dapat menghasilkan uang tergantung kontrak dan persetujuan antara brand dan endorsmen. Adapun 5 pemain dengan gaji tertinggi di Chelsea yang memanfaatkan Instagram sebagai platform marketing, yaitu : Kepa Arizabalaga, Ben Chilwell, Timo Werner, N'Golo Kante dan Romelu Lukaku. Tujuan dari penelitian ini adalah untuk menghitung kreabilitas Image Comments to Followers Ratio pada pemain dengan gaji tertinggi di Chelsea. Metode yang digunakan untuk penelitian ini yaitu metode eksploratif kuantitatif. Hasil dari penelitian ini menunjukan bahwa pemain Kepa Arizabalaga mendapatkan peringkat pertama dan memiliki kreabilitas performa akun yang baik.
\end{abstract}




\section{PENDAHULUAN}

Instagram adalah sebuah aplikasi berbagi foto dan video yang memungkinkan pengguna mengambil foto, mengambil video, menerapkan filter digital, dan aktivitas berjejaring lainnya.

Nama Instagram berasal dari Kata 'Instan' dan 'telegram'. Kata 'instan' yang mendasari penamaan 'insta' dimaksudkan seperti kamera polaroid yang pada masanya lebih dikenal dengan sebutan "foto instan".

Dengan makna ini Instagram juga dapat menampilkan foto-foto secara instan, seperti polaroid di dalam tampilannya. Sedangkan kata telegram merujuk pada sebuah alat yang bekerja mengirimkan informasi kepada orang lain dengan cepat.

Hal ini sama dengan fungsi Instagram yang dapat mengunggah foto dengan koneksi Internet, sehingga informasi yang ingin disampaikan dapat diterima dengan cepat.

Instagram adalah jejaring sosial yang lahir dari sebuah perusahaan bernama Burbn, Inc. yang berdiri pada 6 Oktober 2010. Perusahaan ini didirikan oleh Kevin Systrom dan Mike Krieger yang saat ini menjadi CEO dari Instagram.

Kedua CEO tersebut memutuskan untuk lebih memfokuskan Burbn pada aplikasi yang memungkinkan penggunanya unruk berbagi foto dan video, berkomentar, dan juga kemampuan untuk menyukai sebuah foto.aplikasi inilah yang merupakan cikal bakal dari Instagram. Awalnya aplikasi ini hanya dapat dinikmati oleh pengguan IPhone.

Pada 9 April 2012, Facebook resmi mengambil alih Instagram senilai hampir \$1 miliar dalam bentuk tunai dan saham. Logo dari Instagram sendiri berupa kamera polaroid yang menggambarkan sebuah aplikasi berbagi foto dan video instan. (Anugerah Ayu Sendari)

Instagram dalam masanya sangat berkembang dengan pesat dan bahkan digemari oleh seluruh remaja di era digital modern ini. Dengan keunggulan yang dimiliki instagram, banyak remaja di era modern menggunakan sosial media ini dengan berbagai macam alasan, tujuan serta pencapaian.

Instagram dalam penggunaannya adalah aplikasi yang mampu mengambil gambar sebuah momen untuk dipublikasikan, mengedit gambar untuk mendapat kesan yang lebih bervariasi dan mengunggah sebagai sarana menyimpan suatu momen yang terjadi.

Seiring dalam perkembangannya, instagram memiliki banyak fungsi yang dapat dinikmati oleh penggunanya, namum disisi lain instagram juga memiliki dampak positif serta dampak negatif nya bagi para remaja yang menggunakannya.

Dampak positif instagram :

- Instagram dapat digunakan sebagai penunjang masalah ekonomi, contohnya online shop. Sudah banyak sekali remaja yang memiliki online shop sendiri dengan menggunakan media instagram 
- Instagram dapat digunakan untuk sarana bersosialisasi, sehingga para remaja bisa meliliki lebih banyak teman

- Instagram dapat digunakan untuk media bersyiar, sekarang sudah banyak ustadz muda yang menggunakan media instagram untuk bersyiar

- Instagram dapat digunakan untuk media belajar dan mencari pengetahuan

Dampak negatif instagram :

- Instagram dapat membuat remaja kecanduan hingga malas belajar karena terlalu asik bermain instagram

- Banyak pengguna instagram yang mengunggah foto-foto berbau pornografi, sehingga banyak remaja yang melakukan pelecehan seksual

- Banyak pengguna instagram yang menyebarkan berita tidak benar atau hoax yang dapat menimbulkan banyak masalah dan menyebabkan remaja percaya dan terhasut oleh berita hoax tersebut ( Finna Yunilia Wijaya )

Penelitian ini menggunakan metode eksploratif kuantitatif dan anak menghitung menggunakan rasio - rasio yang ada pada Instagram. Penelitian ini hanya berfokus untuk menghitung kredibilitas Image Comments to Followers Ratio pada 5 Pemain dengan Gaji Tertinggi di Chelsea. Tujuan dari penelitian ini adalah mengetahui kredibilitas performa dari akun Instagram 5 Pemain dengan Gaji Tertinggi menggunakan Image Comments to Followers Ratio.

\section{TINJAUAN PUSTAKA}

Perkembangan bidang teknologi saat ini terjadi begitu pesat. Melalui perkembangan yang terjadi dari waktu ke waktu menimbulkan maraknya aplikasi - aplikasi serta platform media sosial yang bermunculan. Aplikasi yang sangat diminati oleh masyarakat saat ini diantaranya adalah Instagram, TikTok Facebook, WhatsApp dan yang lain sebagainya. Seiring berjalannya waktu, aplikasi sosial media tersebut dapat menjadi candu bagi kalangan masyarakat. Tidak hanya kalangan remaja yang menggunakan aplikasi sosial media, orang tua bahkan anak-anak juga aktif menggunakan aplikasi sosial media tersebut.

Instagram secara sederhana dapat didefinisikan sebagai aplikasi mobile berbasis iOS, Android dan Windows Phone dimana pengguna dapat membidik, meng-edit dan memposting foto atau video ke halaman utama Instagram dan jejaring sosial lainnya.

Foto atau video yang dibagikan nantinya akan terpampang di feed pengguna lain yang menjadi follower Anda. Sistem pertemanan di Instagram menggunakan istilah following dan follower. Following berarti Anda mengikuti pengguna, sedangkan follower berarti pengguna lain yang mengikuti Anda. Selanjutnya setiap pengguna dapat berinteraksi dengan cara memberikan komentar dan memberikan respon suka terhadap foto yang dibagikan. Instagram awalnya dikembangkan oleh startup bernama Burbn, Inc yang dimotori oleh Kevin Systrom dan Mike Krieger. Di tangan keduanya Instagram sukses membuat raksasa jejaring sosial Facebook bertekuk lutut sehingga bersedia membelinya seharga $\$ 1$ miliar, akuisisi itu terjadi pada 9 April 2012 ( Bambang Winarso 2015 ). 
Perusahaan ini didirikan oleh Kevin Systrom dan Mike Krieger, keduanya lulusan Universitas Stanford, pada 2010 dan kini memiliki sekitar 200 juta pengguna. Facebook, raksasa jaringan sosial, mengakuisisi perusahaan tersebut pada tahun 2012. Meskipun premis dasarnya adalah berbagi gambar, popularitas situs ini berasal dari fungsi pengeditan gambarnya.

Setelah pengguna mengambil gambar, filter-filter Instagram dapat mengubah gambar dengan berbagai macam jenis filter yang tersedia. Fungsi Instagram ini memungkinkan pembuatan profil pribadi tetapi juga dapat dihubungkan ke profil jejaring sosial yang ada seperti Facebook dan Twitter, yang berarti pengguna dapat berbagi foto mereka di seluruh platform tersebut (Edelweis Lararenjana 2021).

Instagram semakin berkembang pesat hingga saat ini. Dengan menggunakan layanan posting melalui foto dan video, instagram tidak hanya dijadikan sekadar media bersenang-senang saja akan tetapi juga dapat dimanfaatkan oleh banyak pelaku bisnis untuk memasarkan produknya. Dan kini, banyak online shop yang menggunakan instagram untuk media mempromosikan barang atau jasa mereka. Hingga saat ini, sudah tidak lagi terhitung berapa jumlah online shop yang menggunakan instagram sebagai sarana promosi untuk produknya. Namun sama seperti sosial media lainnya, instagram juga memiliki kelebihan dan kekurangan dalam hal melakukan promosi. (Putri Nowo 2021).

Jika anda sudah memiliki followers yang banyak di Instagram dan menjadi seleb gram (sebutan untuk yang memiliki followers,like,share yang banyak) saat itu bisa mendapatkan uang dari endors/sponsor yang masuk ke akun anda tersebut. Jadi memiliki follower yang banyak di Instagram juga dapat menambah sedikit tidaknya pemasukan uang anda, karena untuk mempromosikan produk diperlukan penonton atau banyak orang yang melihatnya dan itu salah satunya adalah akun Instagram yang banyak memili follower. Selain untuk mendapatkan uang, Instagram juga cocok untuk melakukan promosi seperti memanfaakan endorsmen itu sendiri, menggunakan hastag, Instagram ads ataupun paid promote dan termasuk aplikasi yang mudah dioperasikan serta Instagram juga memang memiliki koneksi dengan beberapa sosial media lainnya sehingga memberikan kemudahan tersendiri untuk para pelaku bisnis/promosi. Jadi Anda tidak perlu lagi menghabiskan banyak waktu hanya untuk memposting di sosial media lain.

Instagram dirasakan memiliki kekuatan ataupun pengaruh dalam industri, sehingga menimbulkan kualitas akun yang menentukan strata maupun kredibilitas pemilik akun. Kredibilitas akun Instagram merupakan suatu hal yang cukup penting untuk berbagai kepentingan. Kredibilitas sebuah akun Instagram dapat diukur dari tingkat performa yang dihasilkan secara matematis. Dalam mengukur performa diperlukan skala pengukuran yang tertuang ke dalam rasio.

\section{METODE PENELITIAN}

Penelitian ini menggunakan metode eksploratif kuantitatif untuk mengetahui kredibilitas dari performa akun Instagram 5 Pemain dengan Gaji Tertinggi di Chelsea. Metode eksploratif merupakan penelitian yang memiliki tujuan untuk melakukan eksplorasi atau memperdalam pengetahuan ataupun ide-ide baru mengenai suatu hal yang baru, untuk merumuskan permasalahan secara terperinci (Maryam, Isrok'atun, and Aeni 2016). 
Tujuan dari penelitian ini yaitu mengetahui nilai kredibillitas dari performa akun Instagram 5 Pemain dengan Gaji Tertinggi di Chelsea. Ada beberapa langkah yang harus dilakukan dalam penelitian ini, sehingga mampu menemukan peringkat pertama akun 5 Pemain dengan Gaji Tertinggi di Chelsea yang memiliki performa terbaik. Langkah-langkah yang dilakukan pada penelitian ini, diantaranya yaitu :

\section{Melakukan Eksplorasi Pada Website Untuk Menentukan Objek yang Akan Dianalisa.}

Eksplorasi ini dilakukan pada beberapa halaman website yang menyediakan informasi mengenai objek yang akan di teliti. Setelah ekslorasi selesai dilakukan, sehingga ditemukan nama-nama vendor smartphone di Indonesia yang akan dijadikan objek analisa. Setelah melakukan eksplorasi pada halaman website, maka langkah selanjutnya yaitu mencari nama akun Instagram dari masing-masing vendor smartphone. Pastikan semua vendor memiliki akun pada aplikasi sosial media Instagram.

\section{Menghitung Nilai Rata-Rata Variable Dari 5 Pemain dengan Gaji Tertinggi di Chelsea.}

Pada langkah ini, peneliti menghitung nilai variabel image comments dan variable Followers. Variabel merupakan sesuatu yang memiliki nilai bervariasi dimana nilai tersebut dapat dijadikan sebagai dasar untuk tempat data yang berbeda seperti rasio, skala, ordinal, nominal dan internal (Rankuti 2015). Untuk menghitung nilai rata-rata dari variabel image comments dan variable Followers yaitu dengan cara mengambil minimal 10 postingan kemudian di hitung sehingga menemukan nilai rata-rata dari masing-masing variabel.

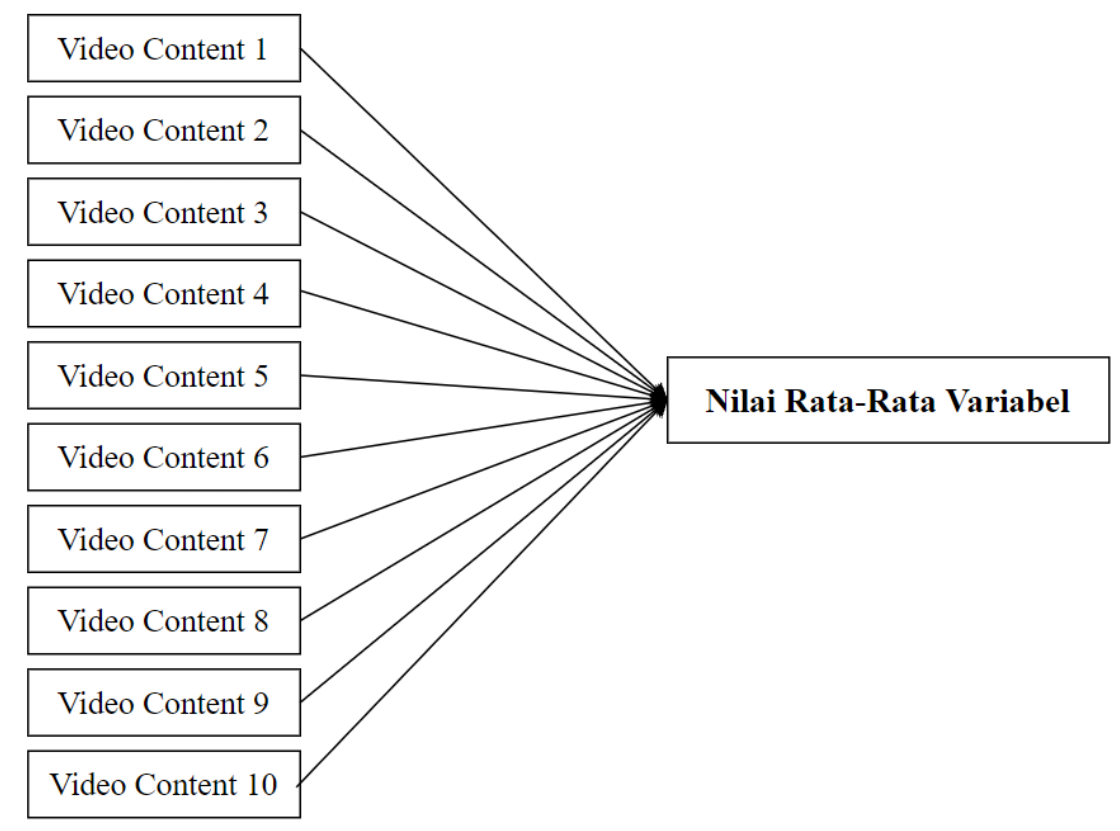

Gambar 1. Analisa Nilai Rata-Rata Variabel.

\section{Menghitung Nilai Kredibilitas Rasio}

Untuk menghitung nilai kredibilitas dari image comments to followers ratio, peneliti menggunakan cara membagi nilai variabel pertama dengan nilai variabel kedua. Jika 
image comments memiliki nilai 100 dan followers memiliki nilai 300, maka cara menghitungnya yaitu $100: 300=0,3$. Dengan begitu nilai dari image comments to followers ratio adalah 0,3 .

\section{Menentukan Peringkat Pada Akun TikTok}

Pada langkah terakhir yang dilakukan pada penelitian ini yaitu menentukan peringkat pada masing-masing rasio yang ada. Pada penentuan peringkat perlu melihat karakteristik dari rasio yang di teliti. Jika karakteristik rasio merupakan rendah, maka objek yang memiliki nilai terendah akan mendapatkan angka 5 dan objek yang memiliki nilai tertinggi akan mendapatkan angka 1 . Namun jika rasio memiliki karakteritik tinggi maka objek yang mendapatkan nilai tinggi akan mendapatkan angka 5 dan objek yang mendapatkan nilai terendah akan mendapatkan angka 1. Setelah mendapatkan hasil kredibilitas ratio maka dapat disimpulkan objek yang mana mendapatkan peringkat 1 sampai dengan peringkat 5 .

\section{HASIL DAN PEMBAHASAN}

Akun Instagram 5 Pemain Gaji Tertinggi di Chelsea, diantaranya :

\section{Kepa Arizabalaga}

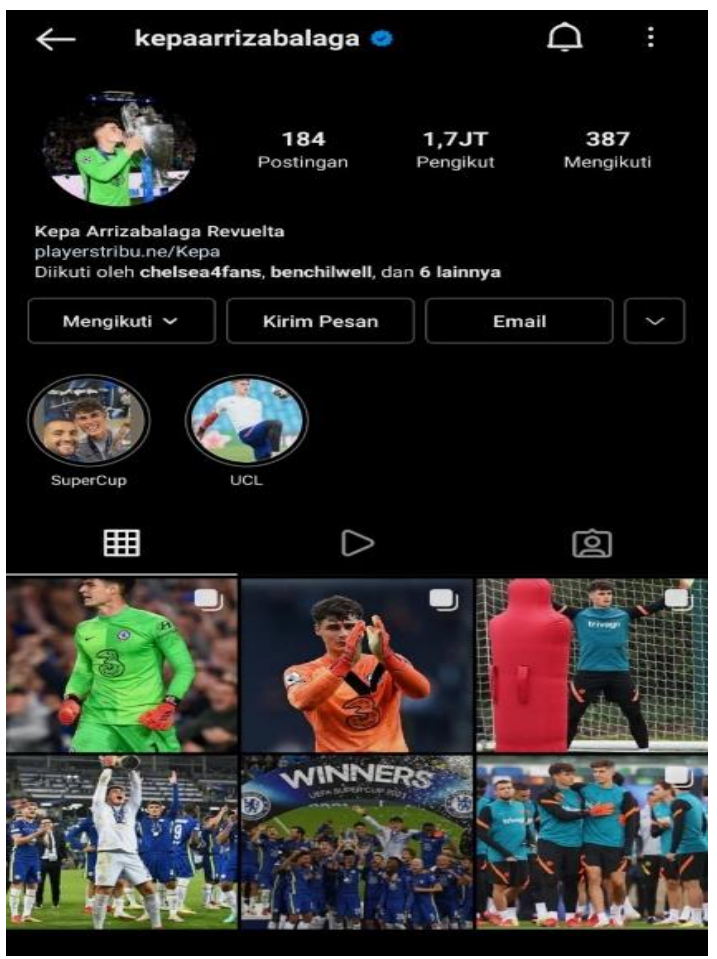

Gambar 1. Akun Instagram Kepa Arizabalaga

Sumber : https://www.instagram.com/kepaarrizabalaga/ (akses pada 13-10-2021) 


\section{Ben Chilwell}

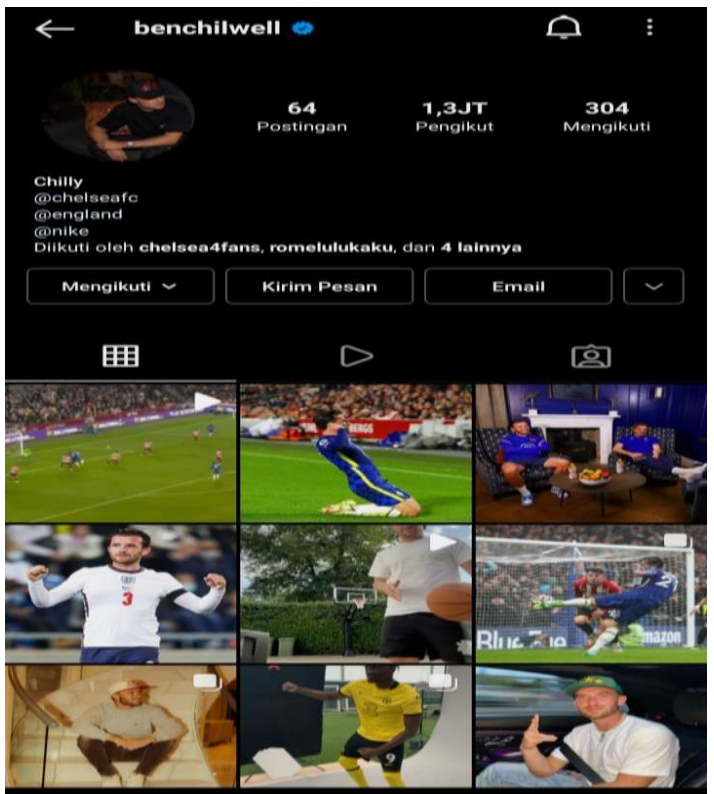

Gambar 2. Akun Instagram Ben Chilwell

Sumber : https://www.instagram.com/benchilwell/ (akses pada 13-10-2021)

\section{Timo Werner}

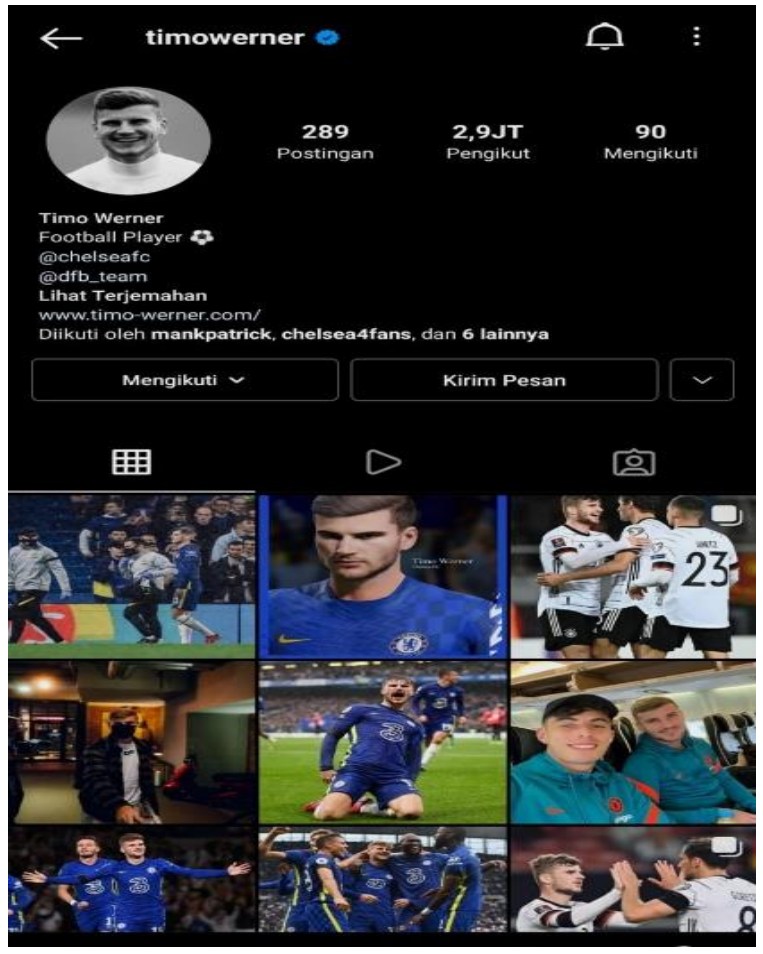

Gambar 3. Akun Instagram Timo Werner

Sumber : https://www.instagram.com/timowerner/ (akses pada 13-10-2021) 


\section{N'Golo Kante}

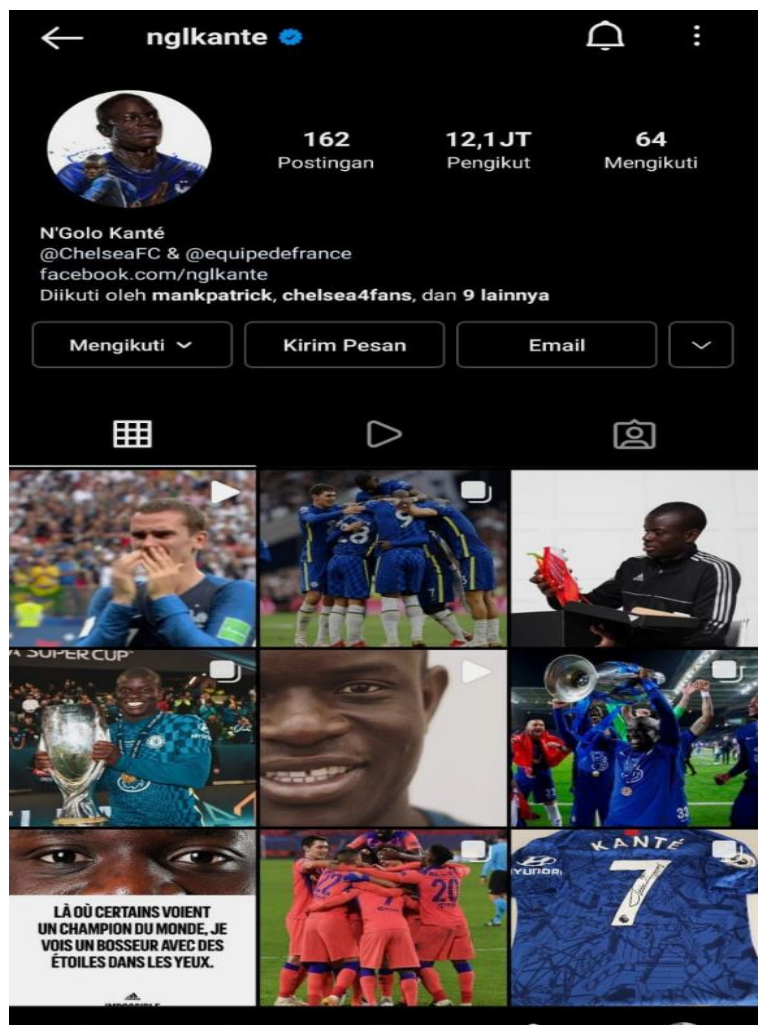

Gambar 4. Akun Instagram N’Golo Kante

Sumber : https://www.instagram.com/nglkante/ (akses pada 13-10-2021)

\section{Romelu Lukaku}

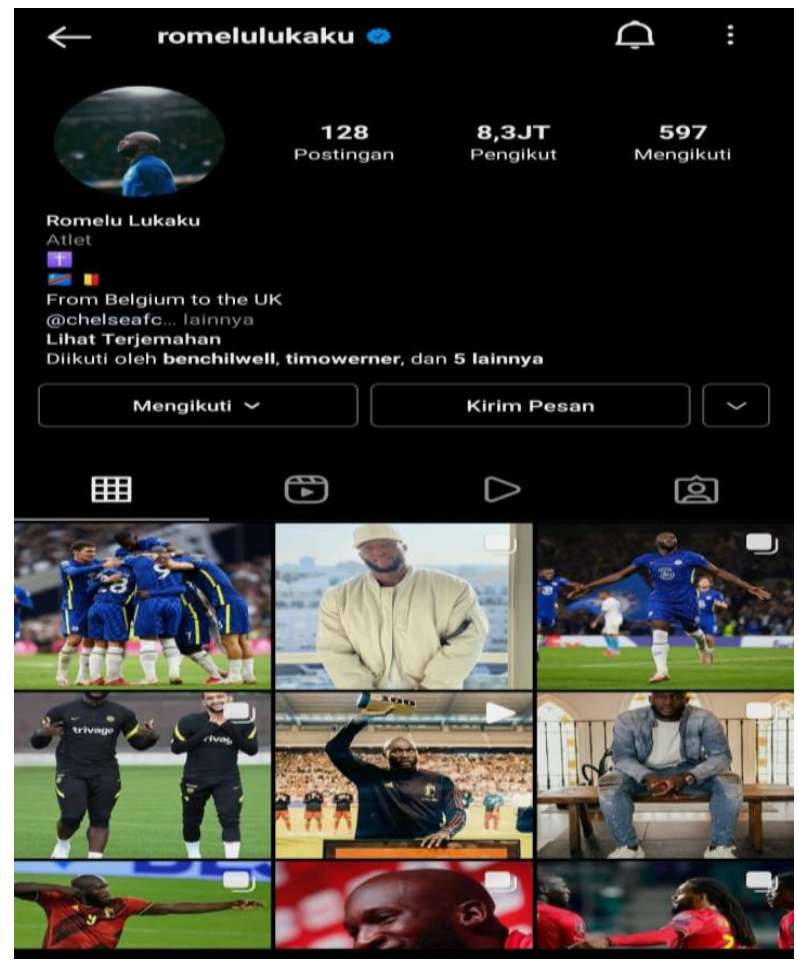

Gambar 5. Akun Instagram Romelu Lukaku

Sumber : https://www.instagram.com/romelulukaku/ (akses pada 13-10-2021) 
Dari kelima akun Instagram 5 Pemain Gaji Tertinggi di Chelsea, peneliti menemukan nilai dari masing-masing variabel yang ada untuk menghitung rasio Image Comments to Followers dari setiap akun. Pada akun Instagram terdapat 10 variabel, diantaranya yaitu :

1. Image Likes

2. Image Comments

3. Followers

4. Following

5. Video Likes

6. Video Comments

7. Post

8. DM

9. Foto, Video Share

10. Video Views

Dari kesepuluh variabel tersebut peneliti hanya fokus untuk menemukan hasil dari 3 variabel, yaitu :

1. Image Likes

2. Image Comment

3. Followers

Dari ketiga variabel tersebut kemudian dianalisa sehingga menemukan nilai rata-rata dari variabel Image comments dan variabel Followers. Untuk menghitung nilai rata-rata dari variabel Image comments yaitu dengan cara mengambil minimal 10 postingan kemudian di hitung sehingga menemukan nilai rata-rata dari masing-masing variabel dan cara mengambil Followers itu langsung melihat di akun Instagram. Berikut merupakan tabel nilai rata-rata dari masing-masing pemain di Chelsea,

yaitu :

Tabel 1. Analisa Nilai Rata-Rata Nilai Variabel Image Likes dan Image Comments dan jumlah Followers Akun Kepa Arizabalaga

\begin{tabular}{|c|r|r|}
\hline \multicolumn{2}{|l|}{ Kepa Arizabalaga } & \\
\hline No & Image Likes & Image Comment \\
\hline 1 & 358.755 & 3.950 \\
\hline 2 & 394.503 & 4.596 \\
\hline 3 & 182.941 & 741 \\
\hline 4 & 327.345 & 3.463 \\
\hline 5 & 386.504 & 10.151 \\
\hline 6 & 254.714 & 2.084 \\
\hline 7 & 216.350 & 620 \\
\hline 8 & 151.367 & 1.076 \\
\hline 9 & 179.413 & 534 \\
\hline 10 & 193.734 & 1.204 \\
\hline Total & $\mathbf{2 6 4 . 5 6 3}$ & $\mathbf{2 . 8 4 2}$ \\
\hline
\end{tabular}

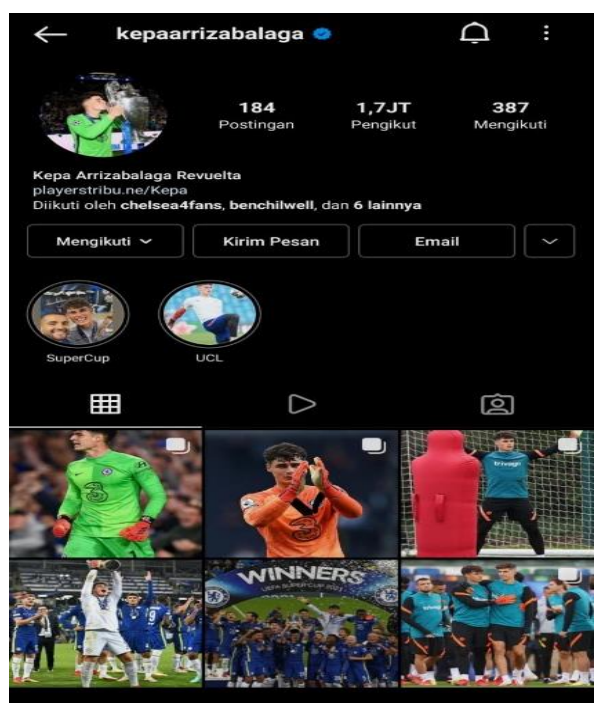

Sumber : Pengolah Data Excel dan akun Instagram 
Tabel 2. Analisa Nilai Rata-Rata Nilai Variabel Image Likes dan Image Comments dan jumlah Followers Akun Ben Chilwell

\begin{tabular}{|c|r|r|}
\hline \multicolumn{2}{|l|}{ Ben Chilwel } \\
\hline No & Image Likes & Image Comment \\
\hline 1 & 17.705 & 2 \\
\hline 2 & 209.394 & 29 \\
\hline 3 & 310.903 & 27 \\
\hline 4 & 167.398 & 6 \\
\hline 5 & 197.317 & 5 \\
\hline 6 & 299.820 & 14 \\
\hline 7 & 274.132 & 5 \\
\hline 8 & 266.734 & 7 \\
\hline 9 & 171.083 & 8 \\
\hline 10 & 211.789 & 11 \\
\hline Total & $\mathbf{2 1 2 . 6 2 8}$ & $\mathbf{1 1}$ \\
\hline
\end{tabular}

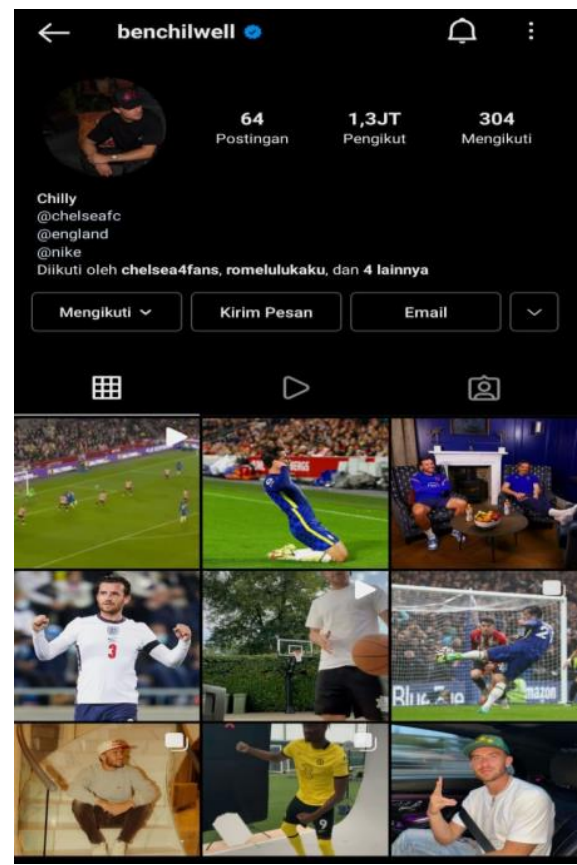

Sumber : Pengolah Data Excel dan akun instagram

Tabel 3. Analisa Nilai Rata-Rata Nilai Variabel Image Likes dan Image Comments dan jumlah Followers Akun Timo Werner

\begin{tabular}{|c|r|r|}
$\mid$ Timo Werner \\
\hline No & Image Likes & Image Comment \\
\hline 1 & 271.039 & 1.566 \\
\hline 2 & 169.639 & 764 \\
\hline 3 & 601.803 & 12.471 \\
\hline 4 & 348.055 & 1.400 \\
\hline 5 & 411.946 & 3.838 \\
\hline 6 & 429.943 & 4.158 \\
\hline 7 & 249.655 & 1.182 \\
\hline 8 & 196.685 & 787 \\
\hline 9 & 316.865 & 1.229 \\
\hline 10 & 309.186 & 727 \\
\hline Total & $\mathbf{3 3 0 . 4 8 2}$ & $\mathbf{2 . 8 1 2}$ \\
\hline
\end{tabular}

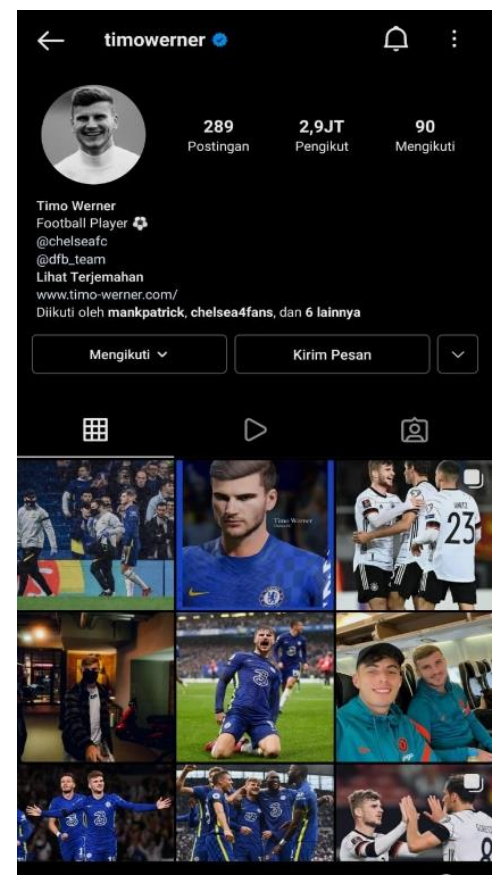

Sumber : Pengolah Data Excel dan akun Instagram 
Tabel 4. Analisa Nilai Rata-Rata Nilai Variabel Image Likes dan Image Comments dan jumlah Followers Akun N'Golo Kante

\begin{tabular}{|c|r|r|}
\multicolumn{2}{|l|}{ N'Golo Kante } \\
\hline No & Image Likes & Image Comment \\
\hline 1 & 1.527 .043 & 8.517 \\
\hline 2 & 796.284 & 4.646 \\
\hline 3 & 2.403 .536 & 13.700 \\
\hline 4 & 3.633 .770 & 76.587 \\
\hline 5 & 674.555 & 13.239 \\
\hline 6 & 1.017 .443 & 14.289 \\
\hline 7 & 929.197 & 9.029 \\
\hline 8 & 969.483 & 3.976 \\
\hline 9 & 684.455 & 1.109 \\
\hline 10 & 587.717 & 2.414 \\
\hline Total & 1.322 .348 & 14.751 \\
\hline
\end{tabular}

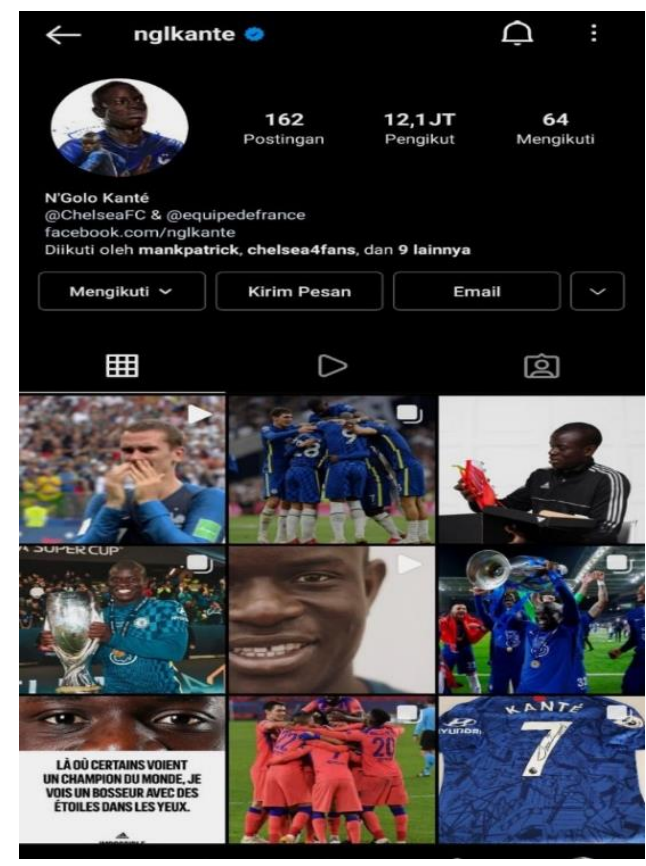

Sumber : Pengolah Data Excel dan akun instagram

Tabel 5. Analisa Nilai Rata-Rata Nilai Variabel Image Likes dan Image Comments dan jumlah Followers Akun Romelu Lukaku

\begin{tabular}{|c|r|r|}
\hline \multicolumn{2}{|l|}{ Romelu Lukaku } \\
\hline No & Image Likes & Image Comment \\
\hline 1 & 470.864 & 3.553 \\
\hline 2 & 986.453 & 6.834 \\
\hline 3 & 841.364 & 5.815 \\
\hline 4 & 746.083 & 3.200 \\
\hline 5 & 781.006 & 5.010 \\
\hline 6 & 572.936 & 1.944 \\
\hline 7 & 356.672 & 1.476 \\
\hline 8 & 470.449 & 2.249 \\
\hline 9 & 370.037 & 1.501 \\
\hline 10 & 498.795 & 1.780 \\
\hline Total & $\mathbf{6 0 9 . 4 6 6}$ & $\mathbf{3 . 3 3 6}$ \\
\hline
\end{tabular}

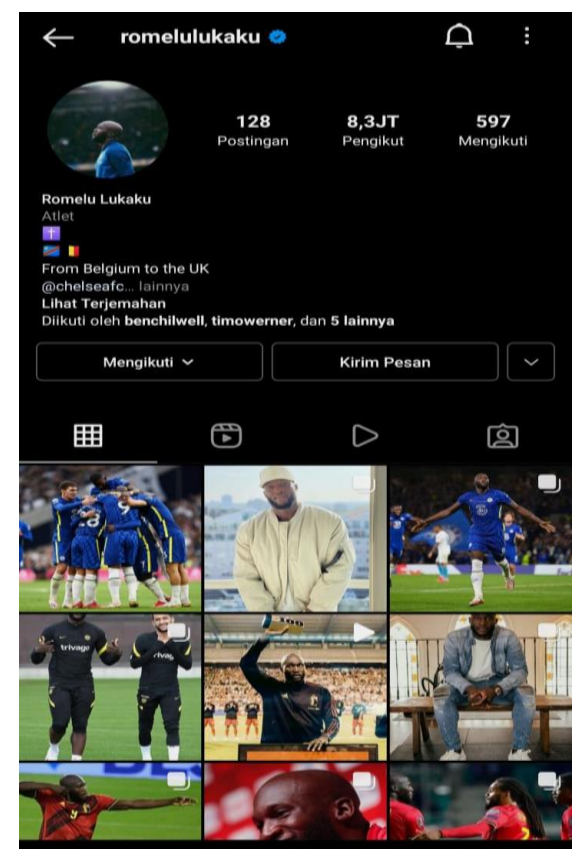

Sumber : Pengolah Data Excel dan akun Instagram 
Setelah menghitung nilai rata-rata tersebut, maka akan menemukan hasil akhir nilai rata-rata dari variabel image comments dan variable Followers

Tabel 6. Nilai Variabel Pada Akun Instagram 5 Pemain Gaji Tertinggi di Chelsea

Tabel Nilai Masing-Masing Variable

\begin{tabular}{|l|r|r|r|r|r|}
\hline \multicolumn{1}{|c|}{ Variable } & Kepa Arizabalaga & \multicolumn{1}{c|}{ Ben Chilwel } & \multicolumn{1}{c|}{ Timo Werner } & \multicolumn{1}{c|}{ N'Golo Kante } & \multicolumn{1}{c|}{ Romelu Lukaku } \\
\hline Image Likes & 264.563 & 212.628 & 330.482 & 1.322 .348 & 609.466 \\
\hline Image Comments & 2.842 & 11 & 2.812 & 14.751 & 3.336 \\
\hline Followers & 1.700 .000 & 1.300 .000 & 2.900 .000 & 12.100 .000 & 8.300 .000 \\
\hline & & & & & \\
\hline
\end{tabular}

Sumber : Pengolah Data Excel

Pada akun Instagram terdapat 17 rasio yang relevan digunakan untuk mengukur kredibilitas pada masing-masing akun. Namun pada penelitian kali ini hanya berfokus untuk menghitung Image Comments to Followers Ratio. Untuk menghitung kredibilitas dari masing-masing akun Instagram setiap vendor smartphone, peneliti menghitung dengan cara : variabel 1(Image Comments) akan dibagi dengan variabel 2 (Followers), sehingga ditemukan hasil analisisa dari rasio tersebut.

Tabel 7. Hasil Perhitungan Rasio Akun Instagram

Tabel Rasio

\begin{tabular}{|c|c|c|c|c|c|c|}
\hline No & RATIO & Kepa Arizabalaga & Ben Chilwel & Timo Werner & N'Golo Kante & Romelu Lukaku \\
\hline 1 & Image Comments to Followers Ratio & 0,00167176 & 0,00000846 & 0,00096966 & 0,00121909 & 0,00040193 \\
\hline & & & & & & \\
\hline & & & & & \\
\hline \multicolumn{7}{|l|}{} \\
\hline
\end{tabular}

Sumber : Pengolah Data Excel

Image Comments to Followers Ratio memiliki karakteristik yang tinggi, artinya semakin tinggi nilai yang dihasilkan maka semakin baik kredibilitas dari performa akun tersebut. Untuk memberikan peringkat pada masing-masing Pemain Chelsea, peneliti memberikan angka 5 kepada pemain yang mendapatkan nilai tertinggi dan angka 1 untuk pemain Chelsea yang mendapatkan nilai terendah. Berikut merupakan tabel urutan nilai yang dihasilkan oleh masingmasing Pemain Chelsea. 
Tabel 8. Nilai Rasio Akun Instagram 5 Pemain Gaji Tertinggi di Chelsea

\begin{tabular}{|c|c|c|c|c|}
\hline \multicolumn{5}{|c|}{ Tabel Peringkat } \\
\hline Kepa Arizabalaga & Ben Chilwel & Timo Werner & N'Golo Kante & Romelu Lukaku \\
\hline 5 & 1 & 3 & 4 & 2 \\
\hline
\end{tabular}

Sumber : Pengolah Data Excel

Dari Tabel Nilai Rasio Akun Instagram 5 Pemain Gaji Tertinggi di Chelsea dapat simpulkan bahwa Kepa Arizabalaga mendapatkan nilai tertinggi untuk rasio Image Comments to Followers. Sedangkan akun Instagram Ben Chilwell mendapatkan nilai terendah untuk rasio ini. Jadi, pada penelitian ini Kepa Arizabalaga memiliki kredibilitas performa yang lebih baik dibandingkan dengan Pemain Chelsea yang lainnya.

\section{KESIMPULAN}

Tujuan dari penelitian ini adalah mengetahui kredibilitas performa dari akun Instagram 5 Pemain Gaji Tertinggi menggunakan Image Comments to Followers Ratio. 5 Pemain Chelsea tersebut diantaranya : Kepa Arizabalaga, Ben Chilwell, Timo Werner, N'Golo Kante dan Romelu Lukaku . Dari kelima pemain Chelsea tersebut dapat disimpulkan bahwa :

1. Peringkat pertama diraih oleh pemain Kepa Arizabalaga dengan nilai tertinggi yaitu 0.00167176

2. Peringkat kedua diraih oleh pemain N'Golo Kante dengan nilai 0.00121909

3. Peringkat ketiga diraih oleh pemain Timo Werner dengan nilai 0.00096966

4. Peringkat keempat diraih oleh pemain Romelu Lukaku dengan nilai 0.00040193

5. Peringkat kelima diraih oleh pemain Ben Chilwell dengan nilai terendah yaitu 0.00000846 


\section{DAFTAR PUSTAKA}

Anugerah Ayu sendari 2019 . "Instagram Adalah Platform Berbagi Foto dan Video, Ini Deretan Fitur Canggihnya" https://www.liputan6.com/tekno/read/3906736/instagram-adalah-platform-berbagifoto-dan-video-ini-deretan-fitur-canggihnya

Finna Yunilia Wijaya 2018. "Dampak Positif dan Negatif Instagram bagi Remaja “ https://www.kompasiana.com/finnayuniliawijaya3637/5b07c0f7cf01b47f984c2232/da mpak-positif-dan-negatif-instagram-bagi-remaja

Bambang Winarso 2015. “Apa Itu Instagram, Fitur dan Cara Menggunakannya? “ https://dailysocial.id/post/apa-itu-instagram

Edelweis Lararenjana 2021. "Berikut Fungsi Instagram yang Paling Utama, Bisa untuk Kembangkan Bisnis" https://www.merdeka.com/jatim/berikut-fungsi-instagram-yang-paling-utama-bisauntuk-kembangkan-bisnis-kln.html

Putri Nowo 2021. "KELEBIHAN DAN KEKURANGAN INSTAGRAM SEBAGAI SARANA PROMOSI"

https://citrahost.com/blog/instagram-sebagai-sarana-promosi/

Maryam, Siti, Isrok'atun Isrok'atun, and Ani Nur Aeni. 2016. "PENDEKATAN

EKSPLORATIF UNTUK MENINGKATKAN KEMAMPUAN REPRESENTASI

MATEMATIS DAN KEPERCAYAAN DIRI SISWA.” Jurnal Pena Ilmiah 1 (1): 55160. https://doi.org/10.23819/PI.V1I1.2984.

Rankuti, Freddy. 2015. "Buku Riset Pemasaran.” 2015. 